\title{
Correlation between low-level viremia and hepatitis B-related hepatocellular carcinoma and recurrence: a retrospective study
}

Furong Sun ${ }^{1}$, Zhifei Liu ${ }^{2}$ and Bingyuan Wang ${ }^{1 *}$ (D)

\begin{abstract}
Background: Low-level viremia generally refers to detectable HBV DNA levels lower than $2000 \mathrm{IU} / \mathrm{mL}$. Studies show that low-level viremia is a risk factor for hepatocellular carcinoma. The aim of this study was to explore the characteristics of low-level viremia patients with hepatitis B-related hepatocellular carcinoma and identify prognostic factors after curative hepatectomy.

Methods: Data from chronic hepatitis B patients with hepatocellular carcinoma receiving curative hepatectomy for the first time in the first hospital of China Medical University were studied. Patients were divided into two groups based on preoperative HBV DNA levels: group 1 (low-level viremia group, HBV DNA $<2000 \mathrm{IU} / \mathrm{mL}$ ) and group 2 (HBV DNA $\geq 2000 \mathrm{IU} / \mathrm{mL}$ ).

Results: Of the 212 patients, 104 patients were in group 1 and 108 patients were in group 2. There was a lower proportion of patients with HBsAg levels $>250 \mathrm{IJ} / \mathrm{mL}$ (the upper limit of detection in our laboratory) in group 1 than in group $2(71.2 \%$ vs. $86.1 \%, P<0.01)$. The percentage of patients with a tumor diameter $<5 \mathrm{~cm}$ was $67.3 \%$ in group 1 and $37.0 \%$ in group $2(P<0.000)$. The percentage of tumor recurrence was $40.4 \%(42)$ in group 1 and $54.6 \%(59)$ in group $2(P<0.05)$. Median recurrence-free survival was 30.1 months in group 1 and 17.6 months in group $2(P<0.01)$. Multivariate analysis showed that a tumor diameter $\geq 5 \mathrm{~cm}$ (hazard ratio $[\mathrm{HR}]=1.819,95 \%$ confidence interval [Cl] 1.193-2.775, $P=0.005)$, intrahepatic metastasis ( $\mathrm{HR}=1.916,95 \% \mathrm{Cl} 1.077-3.407, P=0.027)$, and an HBV DNA level $\geq 100$ $\mathrm{IU} / \mathrm{mL}$ (the lower limit of detection in our laboratory, $\mathrm{HR}=2.943,95 \% \mathrm{Cl} 1.916-4.520, P<0.000$ ) were independent prognostic factors associated with an increased risk of hepatocellular carcinoma recurrence.

Conclusion: Preoperative low-level viremia was related with a long tumor recurrence interval and complete virologic response after curative hepatectomy was associated with a lower risk of hepatocellular carcinoma recurrence.
\end{abstract}

Keywords: Chronic hepatitis B, Hepatocellular carcinoma, Low-level viremia, Alpha-fetoprotein, Virologic response

\footnotetext{
*Correspondence: wangby0908@163.com

'Department of Elderly Gastroenterology, The First Hospital of China Medical University, Shenyang 110001, China

Full list of author information is available at the end of the article
}

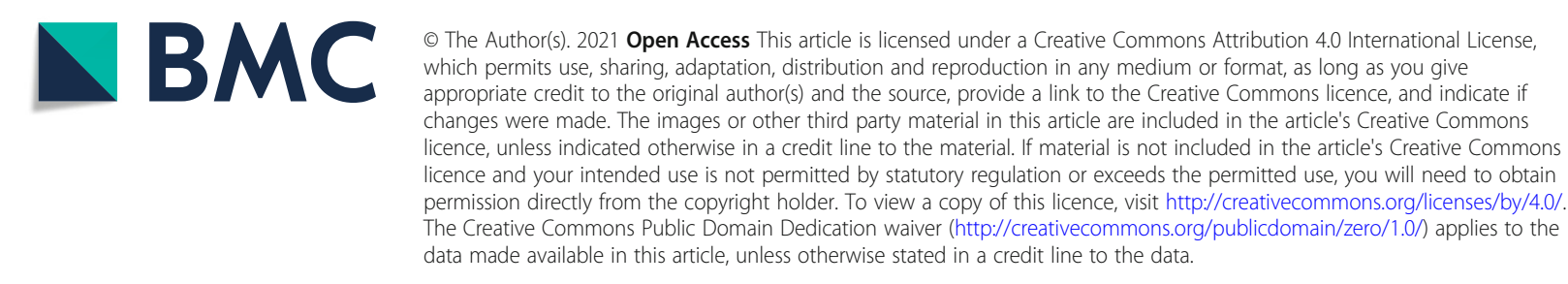




\section{Background}

Hepatitis B viral (HBV) infection remains a serious global public health problem. HBV infection is the leading cause of hepatocellular carcinoma (HCC) worldwide, accounting for $33 \%$ of cases [1]. In China, chronic hepatitis B (CHB) contributes to approximately $84 \%$ of HCC [2]. The incidence of HBV-related deaths due to liver cirrhosis and/or HCC dramatically increased between 1990 and 2013 [3], resulting in a large health and economic burden. Therefore, effective control of $\mathrm{CHB}$ is crucial. Serum HBV DNA level is essential for informing decision-making regarding antiviral treatment and the subsequent monitoring of disease progression. A prospective cohort study showed that an HBV DNA level more than 10,000 copies $/ \mathrm{mL}$ was a strong predictor of HCC development [4]. Long-term, maintained virologic response (VR) is associated with a lack of progression, even in those with decompensated liver cirrhosis [5]. Therefore, an important goal of antiviral treatment is to obtain VR.

Low-level viremia (LLV) can be detected in $\mathrm{CHB}$ patients including those taking antiviral therapy, generally referring to detectable HBV DNA levels lower than $2000 \mathrm{IU} / \mathrm{mL}$. Recently, an increasing number of studies have shown that LLV plays a crucial role in the diagnosis and prognosis of HCC. It has been reported that LLV is associated with a higher risk of HCC and poorer overall survival, compared with those who maintained VR $[6,7]$. LLV patients with a relatively low viral load can still benefit from effective antiviral therapy, showing as significantly decreased risk of HCC [7]. More importantly, antiviral therapy significantly reduced HCC recurrence after R0 hepatic resection [8].

Although the exact incidence of LLV is not known, the potential LLV population is likely considerable. The timing of antiviral therapy for LLV is controversial. Generally, LLV without liver cirrhosis or elevated ALT is considered inactive $\mathrm{CHB}$, and is not an indication for antiviral therapy [2, 9]. However, due to the risk for $\mathrm{HCC}$ and potential benefits of reduced risk of HCC recurrence, it may be necessary for LLV patients to receive antiviral therapy at an earlier $\mathrm{CHB}$ stage and to maintain a long-term VR with undetectable HBV DNA loads. Continuous monitoring of cirrhosis and HCC is also important during routine follow-up.

Characteristics of $\mathrm{CHB}$ have been well described, and studies have revealed common characteristics of LLV. However, an overall understanding of LLV is lacking. Thus, there is still an urgent need to describe LLV characteristics and distinguish LLV patients from other CHB patients. This would help inform suitable management strategies for LLV patients and improve early detection of HCC. In this study, we explored the characteristics of LLV in HCC patients who had undergone curative hepatectomy. Then, prognostic factors were further analyzed in an effort to understand the differential characteristics of LLV patients versus those with high-level viral loads.

\section{Methods \\ Study population}

We obtained data on $\mathrm{CHB}$ patients who had been diagnosed with malignant liver tumors and underwent curative partial hepatectomy by open or laparoscopic hepatectomy in the first hospital of China Medical University between 2011 and 2018. Diagnosis of HCC was based on two types of imaging examinations including liver ultrasound, computed tomography, and magnetic resonance imaging. Diagnosis was further confirmed via analysis of resected specimens.

Inclusion criteria included: (1) first time hepatectomy for HCC, (2) history of $\mathrm{CHB}$ with positive hepatitis $\mathrm{B}$ surface antigen (HBsAg), (3) no extrahepatic metastasis, and (4) above 18 years old. Exclusion criteria included: (1) data incomplete, (2) history of hepatectomy for liver malignant tumors, (3) history of transcatheter arterial chemoembolization for HCC, (4) history of chemotherapy for HCC, (5) special types of HCC confirmed by resected specimens, (6) a combination of $\mathrm{HCC}$ and cholangiocarcinoma, (7) positive hepatitis $C$ surface antibody with increased HCV-RNA loads, (8) secondary malignant tumor of liver. Detailed patient information is shown in Fig. 1. This study was approved and the need for informed consent was waived by the institutional review board of the First Hospital of China Medical University.

\section{Preoperative data}

All patients were divided into two groups based on their preoperative serum HBV DNA levels: Group 1 included patients with serum HBV DNA levels less than $2000 \mathrm{IU} /$ $\mathrm{mL}$, Group 2 included patients with serum HBV DNA levels $\geq 2000 \mathrm{IU} / \mathrm{mL}$.

Medical records were collected and included sex, age, history of antiviral therapy, smoking, and alcohol consumption. An alcohol consumption less than $30 \mathrm{~g} / \mathrm{d}$ for males and $20 \mathrm{~g} / \mathrm{d}$ for females was defined as moderate alcohol consumption; and an alcohol consumption more than $60 \mathrm{~g}$ on one occasion was defined as heavy episodic drinking [10]. Characteristics of liver tumors were carefully recorded, including the number of nodules, the maximum diameter, differentiation, capsule formation, intrahepatic metastasis, satellite nodules, and portal vein tumor thrombosis.

Blood samples were taken after an overnight fasting. Parameters including leukocyte count, hemoglobin, platelet count, alanine aminotransferase (ALT), aspartate aminotransferase (AST), $\gamma$-glutamyl transpeptidase (GGT), 


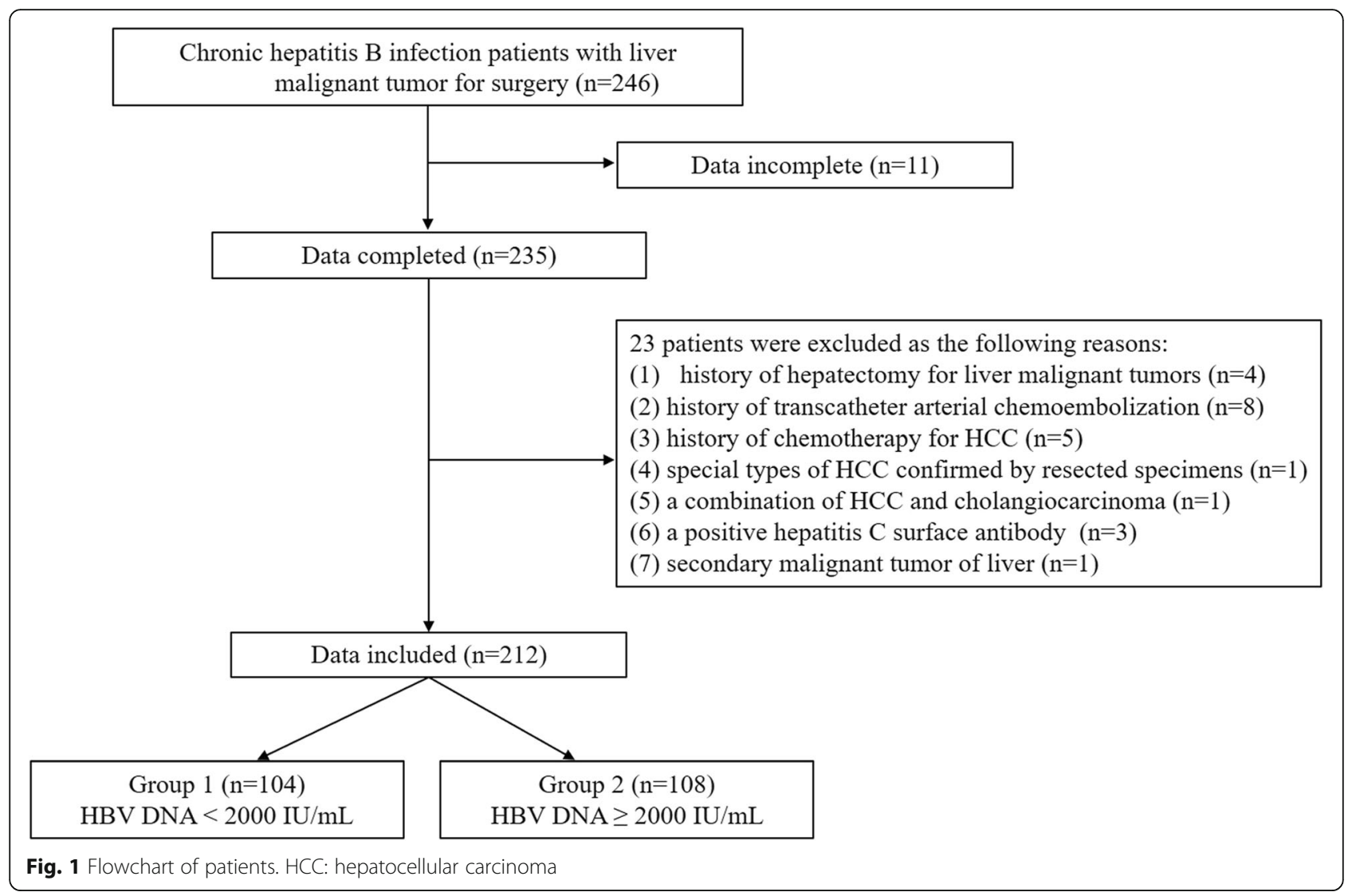

alkaline phosphatase (ALP), serum albumin (ALB), prothrombin time $(\mathrm{PT})$, international normalized ratio (INR), creatinine, alpha-fetoprotein (AFP), HBsAg (upper limit of detection was $250 \mathrm{IU} / \mathrm{mL}$ in our laboratory), serum $\mathrm{HBV}$ DNA (lower limit of detection was $100 \mathrm{IU} / \mathrm{mL}$ in our laboratory), and hepatitis $\mathrm{B}$ e antigen ( $\mathrm{HBeAg}$ ) were then evaluated. Data from preoperative ultrasound, computed tomography, and/or magnetic resonance imaging were also collected.

\section{Follow-up and assessment of recurrence}

All patients were followed-up once every month or once every 3 months at the outpatient department. Patients with detectable HBV DNA or liver cirrhosis were given antiviral therapy pre- and post-operation. Complete VR was defined as the HBV DNA levels persistently lower than $100 \mathrm{IU} / \mathrm{mL}$. Partial VR was defined as the $\mathrm{HBV}$ DNA load decreased by 2 or more log values when compared with the basic viral load. Virological breakthrough was defined as the HBV DNA loads increased by 1 or more log values when compared with the lowest viral load either during the antiviral treatment or redetected during follow-up. Blood samples were taken after an overnight fasting for analysis of liver function, AFP, and HBV DNA levels at every visit. Liver ultrasound, computed tomography, and/or magnetic resonance imaging were taken at the same time to monitor for new lesions in the liver.

Tumor recurrence was defined as (1) new lesions in the liver suspected by liver ultrasound and furthered confirmed by computed tomography or magnetic resonance imaging with or without elevated serum AFP; (2) new lesions in the liver detected by liver ultrasound, computed tomography, or magnetic resonance imaging, and further confirmed in resected specimens.

\section{Statistical analysis}

Continuous variables are presented as mean \pm standard deviation or median (interquartile range). Quantitative variables were compared by Student's $t$ test for continuous variables with a normal distribution or the MannWhitney nonparametric $U$ test. Categorical variables were analyzed by Chi-square test and are expressed as numbers and percentages. Recurrence-free survival was calculated by the Kaplan-Meier method and the differences were compared by log-rank test. Univariate and multivariate analyses were performed by the Cox proportional hazards regression model with stepwise selection of variables. Statistical analysis was performed using IBM SPSS statistics software version 22.0 (IBM, Armonk, NY, USA). A $p$ value $<0.05$ was considered statistically significant. 


\section{Results}

\section{Characteristics of patients}

A total of 169 males and 43 females were enrolled in the study; 104 patients were in group 1 and 108 patients were in group 2 . The mean age was $54.5 \pm 9.6$ years, ranging from 23 to 81 years old. The percentage of patients with a history of smoking or alcohol consumption was 18.4 and $14.2 \%$, respectively. There were no significant differences in sex, age, history of smoking, and alcohol consumption between the two groups $(P>0.05)$. Details are shown in Table 1.

A total of 167 (78.8\%) patients demonstrated a serum HBsAg level $>250 \mathrm{IU} / \mathrm{mL}$, with a lower percentage in group 1 than in group $2(71.2 \%$ vs. $86.1 \%, P<0.01)$. There were $28.8 \%$ patients with positive $\mathrm{HBeAg}$, with a higher percentage in group 2 than in group 1 (39.8\% vs. $17.3 \%, P<0.000)$. Details are shown in Table 1 .

\section{Antiviral treatment}

Most patients had records of antiviral treatment. A total of 196 patients (92.5\%) accepted pre- and post-operative antiviral treatment. Entecavir was administered to 181 patients (85.4\%). Other antiviral agents included lamivudine (five patients), adefovir dipivoxil with or without entecavir (five patients), tenofovir fumarate diofuroxil (two patients), telbivudine (two patients), and interferon $\alpha$ (one patient). Complete VR was observed in 46 patients and 80 patients, pre- and post-operation, respectively, in group 1 . Complete VR and partial VR were observed in 48 patients and 52 patients, pre- and postoperation, respectively, in group 2. More patients in group 1 showed post-operative virological breakthrough than in group 2 (11 vs. 3). Details are presented in Table 2.

\section{Characteristics of tumors}

Liver cirrhosis was observed in most enrolled $\mathrm{CHB}$ patients, with a percentage of $75.0 \%$ in group 1 and $82.4 \%$ in group $2(P>0.05)$. The percentage of well, moderate, and poor differentiation was 19.3\% (39), 64.4\% (130), and $16.3 \%(33)$, respectively $(P>0.05)$. Capsule was observed in $61.3 \%$ (130) of cases, the percentage of tumors with capsule formation was $52.9 \%$ in group 1 and $69.4 \%$ in group $2(P<0.05)$. The percentage of patients with a tumor diameter less than $5 \mathrm{~cm}$ was $67.3 \%$ in group 1 and $37.0 \%$ in group $2(P<0.000)$. Details are shown in Table 1.

\section{Preoperative laboratory tests}

Routine blood tests showed that the mean leukocyte count, platelet count, and hemoglobin were in the normal ranges with no significant difference between groups $(P>0.05)$. Similarly, the mean prothrombin time and international normalized ratio was normal $(P>0.05)$.
Mean ALP and median ALT, AST, and GGT were higher in group 2 than in group $1(P=0.02$ for ALP, $P<$ 0.000 for ALT, AST, and GGT). The mean albumin was lower in group 2 than in group $1(38.8 \pm 3.7$ vs. $41.5 \pm$ 3.5, $P<0.000)$. Median serum AFP concentration was $69.57 \mathrm{ng} / \mathrm{mL}$ for all patients; a much higher median AFP level was observed in patients in group 2 (145.50 vs. $23.09, P<0.01)$. A total of $41(39.4 \%)$ patients in group 1 and $24(22.2 \%)$ patients in group 2 had an AFP level under $10 \mathrm{ng} / \mathrm{mL}(P<0.01)$. Details are shown in Table 1 .

\section{Follow-up}

The median follow-up was 13.5 months. At the end of follow-up, a total of 101 (47.6\%) patients experienced HCC recurrence, $42(40.4 \%)$ patients in group 1 and 59 (54.6\%) patients in group $2(P<0.05)$ (Table 1$)$. Median recurrence-free survival was 30.1 months in group 1 and 17.6 months in group 2 (log-rank $P=0.015, P<0.01$ ) (Fig. 2). A total of 128 patients obtained complete VR during follow-up, exhibiting lower recurrence rate (36.7\% vs. $64.3 \%)$ and longer recurrence-free survival (40.8 months vs. 11.4 months, $P<0.000$ ) compared with patients without complete VR. In patients with tumor recurrence, the percentage of AFP levels $<10 \mathrm{ng} / \mathrm{mL}$ was $35.7 \%(15 / 42)$ and $27.1 \%(16 / 59)$ in group 1 and group 2 , respectively.

Parameters significantly associated with hepatocellular recurrence on univariate analysis were then used for multivariate analysis. Analysis showed that a tumor diameter $\geq 5 \mathrm{~cm}$ (hazard ratio $[\mathrm{HR}]=1.819$, 95\% confidence interval $[\mathrm{CI}] 1.193-2.775, P=0.005)$, intrahepatic metastasis $(\mathrm{HR}=1.916,95 \% \mathrm{CI} 1.077-3.407, P=0.027)$, and an HBV DNA level $\geq 100 \mathrm{IU} / \mathrm{mL} \quad(\mathrm{HR}=2.943,95 \%$ CI 1.916-4.520, $P<0.000)$ were independent prognostic factors associated with an increased risk of $\mathrm{HCC}$ recurrence. Details are shown in Table 3.

\section{Discussion}

In this cohort of $\mathrm{CHB}$ patients with curative hepatectomy, most LLV patients achieved complete VR during follow-up and experienced longer recurrence-free survivals. Post-operative serum HBV DNA levels > 100 $\mathrm{IU} / \mathrm{mL}$ were an independent prognostic factor for HCC recurrence after curative hepatectomy, confirming that complete VR after curative hepatectomy could dramatically improve tumor recurrence-free survivals. Though multivariate analysis showed a lower risk of $\mathrm{HCC}$ recurrence in those with post-operative serum HBV DNA levels $<100 \mathrm{IU} / \mathrm{mL}$, there was still a risk of fibrosis progression and $\operatorname{HCC}[6,11]$. There were 11 patients with preoperative LLV showed virological breakthrough during follow-up. Among them, postoperative HBV DNA loads $\geq 2000 \mathrm{IU} / \mathrm{mL}$ were observed in seven patients (four patients without any 
Table 1 Characteristics of patients and tumors, preoperative laboratory tests, and follow-up

\begin{tabular}{|c|c|c|c|c|}
\hline & $\begin{array}{l}\text { Total } \\
(n=212)\end{array}$ & $\begin{array}{l}\text { Group } 1 \\
(n=104)\end{array}$ & $\begin{array}{l}\text { Group } 2 \\
(n=108)\end{array}$ & $P$ \\
\hline \multicolumn{5}{|l|}{ Characteristics of patients } \\
\hline Age (years) & $54.5 \pm 9.6$ & $55.2 \pm 10.0$ & $53.9 \pm 9.2$ & $>0.05$ \\
\hline Sex (male, \%) & $169(79.7)$ & $84(80.8)$ & $85(78.7)$ & $>0.05$ \\
\hline Smoking (yes, \%) & $39(18.4)$ & $17(16.3)$ & $22(20.4)$ & $>0.05$ \\
\hline \multicolumn{5}{|l|}{ Drinking (yes, \%) } \\
\hline No drinking & $182(85.8)$ & $91(87.5)$ & $91(84.3)$ & \multirow[t]{3}{*}{$>0.05$} \\
\hline Moderate drinking & $21(9.9)$ & $9(8.7)$ & $12(11.1)$ & \\
\hline Heavy episodic drinking & $9(4.2)$ & $4(3.8)$ & $5(4.6)$ & \\
\hline $\mathrm{HBsAg}(>250 \mathrm{IU} / \mathrm{mL}, \%)$ & $167(78.8)$ & $74(71.2)$ & $93(86.1)$ & $<0.01$ \\
\hline Positive HBeAg (n, \%) & $61(28.8)$ & $18(17.3)$ & $43(39.8)$ & $<0.000$ \\
\hline \multicolumn{5}{|l|}{ Preoperative laboratory tests } \\
\hline Leukocyte $\left(10^{9} / \mathrm{L}\right)$ & $5.41 \pm 1.83$ & $5.44 \pm 1.81$ & $5.38 \pm 1.86$ & $>0.05$ \\
\hline Hemoglobin (g/L) & $145.0 \pm 18.8$ & $145.9 \pm 19.2$ & $144.1 \pm 18.5$ & $>0.05$ \\
\hline Platelet $\left(10^{9} / \mathrm{L}\right)$ & $160.4 \pm 70.1$ & $166.8 \pm 68.5$ & $154.3 \pm 71.4$ & $>0.05$ \\
\hline$A L B(g / L)$ & $40.2 \pm 3.9$ & $41.5 \pm 3.5$ & $38.8 \pm 3.7$ & $<0.000$ \\
\hline $\mathrm{ALT}(\mathrm{U} / \mathrm{L})$ & $31(22-46)$ & $25(18-33)$ & $40(28-54)$ & $<0.000$ \\
\hline AST (U/L) & $32(24-46)$ & $26(20-32)$ & $40(31-55)$ & $<0.000$ \\
\hline $\mathrm{ALP}(\mathrm{U} / \mathrm{L})$ & $92.4 \pm 47.4$ & $85.1 \pm 43.1$ & $99.5 \pm 50.5$ & 0.02 \\
\hline GGT (U/L) & $51(32-98)$ & $37(23-60)$ & $74(44-123)$ & $<0.000$ \\
\hline PT (s) & $13.9 \pm 0.9$ & $13.8 \pm 1.0$ & $13.9 \pm 0.9$ & $>0.05$ \\
\hline INR & $1.08 \pm 0.08$ & $1.07 \pm 0.09$ & $1.08 \pm 0.08$ & $>0.05$ \\
\hline Creatinine $(\mu \mathrm{mol} / \mathrm{L})$ & $67.44 \pm 32.75$ & $71.94 \pm 44.76$ & $63.1 \pm 12.15$ & $<0.05$ \\
\hline $\operatorname{AFP}(\mathrm{ng} / \mathrm{mL})$ & $69.57(6.38-1210.00)$ & $23.09(3.65-706.3)$ & $145.50(11.25-1210.00)$ & $<0.01$ \\
\hline AFP < 10 ng/mL (n, \%) & $65(30.7)$ & $41(39.4)$ & $24(22.2)$ & $<0.01$ \\
\hline \multicolumn{5}{|l|}{ Characteristics of tumors } \\
\hline \multicolumn{5}{|l|}{ Differentiation } \\
\hline Well (\%) & $39(19.3)$ & $22(22.2)$ & $17(16.5)$ & \multirow[t]{3}{*}{$>0.05$} \\
\hline Moderate (\%) & $130(64.4)$ & $59(59.6)$ & $71(68.9)$ & \\
\hline Poor (\%) & $33(16.3)$ & $18(18.2)$ & $15(14.6)$ & \\
\hline Cirrhosis & $167(78.8)$ & $78(75.0)$ & $89(82.4)$ & $>0.05$ \\
\hline Diameter $(<5 \mathrm{~cm}, \%)$ & $110(51.9)$ & $70(67.3)$ & $40(37.0)$ & $<0.000$ \\
\hline Metastasis in the liver (yes, \%) & $24(11.3)$ & $10(9.6)$ & $14(13)$ & $>0.05$ \\
\hline Capsule formation (yes, \%) & $130(61.3)$ & $55(52.9)$ & $75(69.4)$ & $<0.05$ \\
\hline \multicolumn{5}{|l|}{ Follow-up } \\
\hline Tumor recurrence (n, \%) & $101(47.6)$ & $42(40.4)$ & $59(54.6)$ & $<0.05$ \\
\hline $\operatorname{AFP}(\mathrm{ng} / \mathrm{mL})$ & $5.86(2.77-195.68)$ & $3.40(2.18-37.77)$ & $16.12(3.68-671.05)$ & $<0.000$ \\
\hline AFP $<10 \mathrm{ng} / \mathrm{mL}(\mathrm{n}, \%)$ & $120(57.1)$ & $71(68.9)$ & $49(45.8)$ & $<0.000$ \\
\hline
\end{tabular}

ALB serum albumin, $A L T$ alanine aminotransferase, AST aspartate aminotransferase, $A L P$ alkaline phosphatase, GGT $\gamma$-glutamyl transpeptidase, $P T$ prothrombin time, INR international normalized ratio, AFP alpha-fetoprotein

record of antiviral treatment), with shorter tumor recurrence-free survivals (less than 6 months in five patients). These results indicate that LLV without effective antiviral treatment is a risk factor for $\mathrm{HCC}$ recurrence. Effective antiviral treatment and complete VR are important for LLV patients.

Serum HBsAg levels are an important characteristic of $\mathrm{CHB}$ and useful for identifying stage of disease and 
Table 2 Antiviral treatment and virological response

\begin{tabular}{|c|c|c|c|}
\hline & $\begin{array}{l}\text { Total } \\
(n=212)\end{array}$ & $\begin{array}{l}\text { Group } 1 \\
(n=104)\end{array}$ & $\begin{array}{l}\text { Group } 2 \\
(n=108\end{array}$ \\
\hline Antiviral treatment, n (\%) & $196(92.5)$ & $95(91.3)$ & $101(93.5)$ \\
\hline data not available, n (\%) & $16(7.5)$ & $9(8.7)$ & $7(6.5)$ \\
\hline Preoperative complete VR, n (\%) & $46(21.7)$ & $46(44.2)$ & - \\
\hline Post-operative complete VR, n (\%) & $128(60.4)$ & $80(76.9)$ & $48(44.4)$ \\
\hline Post-operative partial VR, n (\%) & $53(25.0)$ & $1(1.0)$ & $52(48.1)$ \\
\hline Post-operative virological breakthrough, n (\%) & $14(6.6)$ & $11(10.6)$ & $3(2.8)$ \\
\hline
\end{tabular}

$V R$ virological response

effects of nucleos(t)ide analogues therapy [12, 13]. More importantly, HBsAg levels are associated with the risk of progression to HCC, especially in LLV patients with negative $\mathrm{HBeAg}$ [14]. In this cohort, a total of 167 patients showed serum HBsAg concentrations > $250 \mathrm{IU} /$ $\mathrm{mL}$, possibly reflecting high amount and enhanced transcriptional activity of covalently closed circular DNA inside the hepatocytes [15]. As we know, HBsAg declines very slowly in the most cases through the nature course, even HBV DNA has been undetectable [16]. Therefore, serum HBsAg levels could be an important indicator for monitoring antiviral treatment in those with LLV or even undetectable HBV DNA. Initial therapeutic target may be at a level of $100 \mathrm{IU} / \mathrm{mL}$, because serum HBsAg levels less than $100 \mathrm{IU} / \mathrm{mL}$ suggested a high probability of spontaneous HBsAg clearance [15]. Unfortunately, we could not detect the exact quantitative HBsAg levels in these patients, limited to the test method in our laboratory. Further studies are needed to explore the role of serum HBsAg on CHB control and even in HCC development.

The main difference in tumor characteristics between the two groups was tumor diameter, an important prognostic factor in HCC patients [17]. Multivariate analysis verified that a tumor diameter $\geq 5 \mathrm{~cm}$ and intrahepatic metastasis were two independent prognostic factors for recurrence of $\mathrm{HCC}$ after curative hepatectomy. However, the cases of intrahepatic metastasis were not high in this cohort, probably due to the curative hepatectomy. Thus, tumor diameter seems a much more important characteristic among LLV patients in this cohort. As we

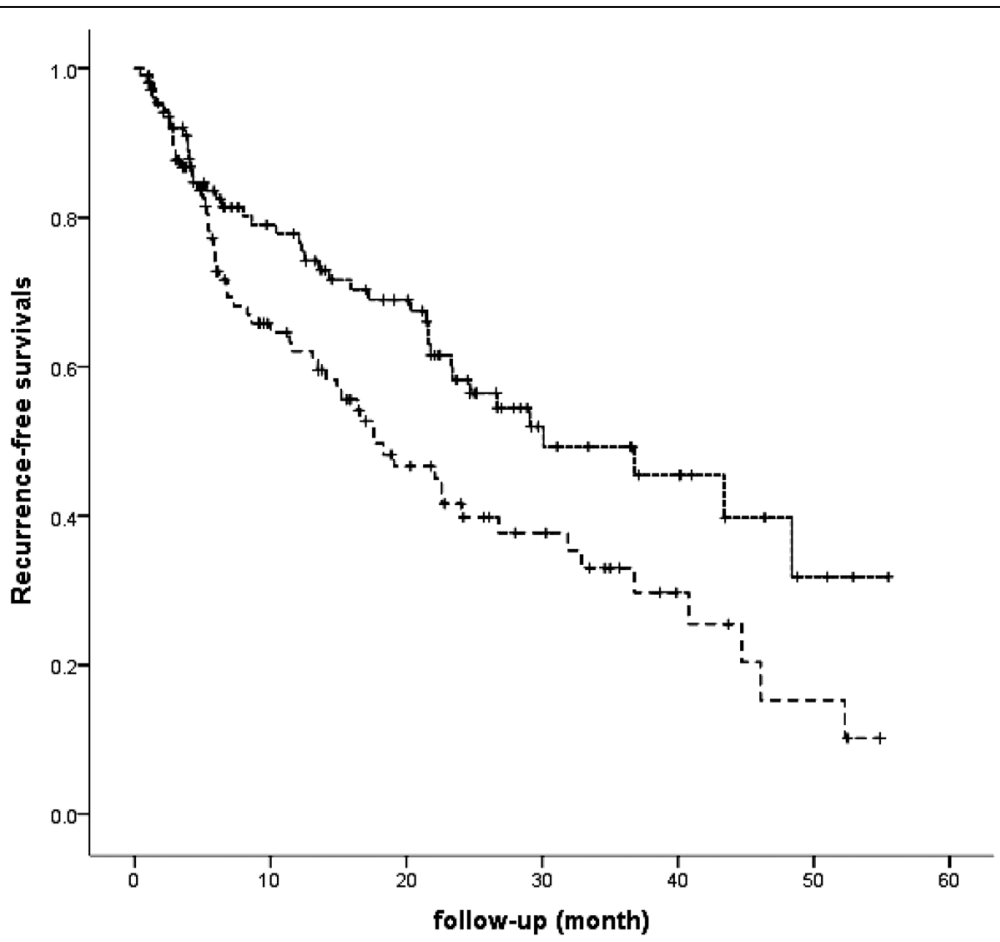

Fig. 2 Comparison of tumor recurrence-free survival between the 2 groups. Kaplan-Meier curve of tumor recurrence-free survival based on preoperative HBV DNA levels. The median tumor recurrence-free survival was 30.1 months in group 1 and 17.6 months in group $2(P<0.01)$ $(\log -\operatorname{rank} P=0.015)$ 
Table 3 Univariate and multivariate analyses for recurrence of hepatocellular carcinoma

\begin{tabular}{|c|c|c|c|c|c|}
\hline \multirow[t]{2}{*}{ Factors } & \multirow{2}{*}{$\begin{array}{l}\text { No. } \\
\text { Patients }\end{array}$} & \multicolumn{2}{|l|}{ Univariate Analysis } & \multicolumn{2}{|l|}{ Multivariate Analysis } \\
\hline & & HR (95\% Cl) & $P$ & HR (95\% Cl) & $P$ \\
\hline \multicolumn{6}{|l|}{ Sex } \\
\hline Male & $169(79.7 \%)$ & $0.850(0.509-1.419)$ & 0.533 & & \\
\hline Female & $43(20.3 \%)$ & & & & \\
\hline \multicolumn{6}{|c|}{ HBV DNA level preoperation } \\
\hline$<2000 \mathrm{IU} / \mathrm{mL}$ & $104(49.1 \%)$ & $1.629(1.095-2.423)$ & 0.016 & $1.007(0.653-1.553)$ & 0.976 \\
\hline$\geq 2000 \mathrm{IU} / \mathrm{mL}$ & $108(50.9 \%)$ & & & & \\
\hline \multicolumn{6}{|l|}{ Cirrhosis } \\
\hline Yes & $167(78.8 \%)$ & $0.812(0.513-1.286)$ & 0.375 & & \\
\hline No & $45(21.2 \%)$ & & & & \\
\hline \multicolumn{6}{|l|}{ Tumor diameter } \\
\hline$<5 \mathrm{~cm}$ & $110(51.9 \%)$ & $1.934(1.300-2.877)$ & 0.001 & $1.819(1.193-2.775)$ & 0.005 \\
\hline$\geq 5 \mathrm{~cm}$ & $102(48.1 \%)$ & & & & \\
\hline \multicolumn{6}{|l|}{ Capsule formation } \\
\hline Yes & $130(61.3 \%)$ & $0.850(0.573-1.261)$ & 0.42 & & \\
\hline No & $82(38.7 \%)$ & & & & \\
\hline \multicolumn{6}{|c|}{ Metastasis in the liver } \\
\hline Yes & $24(11.3 \%)$ & $2.077(1.196-3.607)$ & 0.009 & $1.916(1.077-3.407)$ & 0.027 \\
\hline No & $188(88.7 \%)$ & & & & \\
\hline \multicolumn{6}{|l|}{ AFP preoperation } \\
\hline$<10 \mathrm{ng} / \mathrm{mL}$ & 65 (30.7\%) & $1.714(1.089-2.698)$ & 0.02 & $1.462(0.919-2.324)$ & 0.109 \\
\hline$\geq 10 \mathrm{ng} / \mathrm{mL}$ & $147(69.3 \%)$ & & & & \\
\hline \multicolumn{6}{|l|}{$\mathrm{HBsAg}$} \\
\hline$<250 \mathrm{IU} / \mathrm{mL}$ & $45(21.2 \%)$ & $1.042(0.644-1.686)$ & 0.867 & & \\
\hline$\geq 250 \mathrm{IU} / \mathrm{mL}$ & $167(78.8 \%)$ & & & & \\
\hline \multicolumn{6}{|l|}{$\mathrm{HBeAg}$} \\
\hline Positive & $61(28.8 \%)$ & $1.162(0.765-1.764)$ & 0.481 & & \\
\hline Negative & $151(71.2 \%)$ & & & & \\
\hline \multicolumn{6}{|c|}{ HBV DNA level at follow-up } \\
\hline$<100 \mathrm{IU} / \mathrm{mL}$ & $128(60.4 \%)$ & $2.725(1.836-4.044)$ & $<0.000$ & $2.943(1.916-4.520)$ & $<0.000$ \\
\hline$\geq 100 \mathrm{IU} / \mathrm{mL}$ & 84 (39.6\%) & & & & \\
\hline
\end{tabular}

Data showed that a tumor diameter $\geq 5 \mathrm{~cm}(\mathrm{HR}=1.819,95 \% \mathrm{Cl} 1.193-2.775, P=0.005)$, intrahepatic metastasis $(\mathrm{HR}=1.916,95 \% \mathrm{Cl} 1.077-3.407, P=0.027)$, and an HBV DNA level $>100 \mathrm{IU} / \mathrm{mL}(\mathrm{HR}=2.943,95 \% \mathrm{Cl} 1.916-4.520, P<0.000)$ were independent prognostic factors for $\mathrm{HCC}$ recurrence. $H R$ hazard ratio, $\mathrm{Cl}$, confidence interval

showed, there were $67.3 \%$ LLV patients with tumor diameter $<5 \mathrm{~cm}$, which might be related with a lower tumor recurrence rate. However, more studies are needed to confirm this. Besides, small tumor size may be related with less serious liver injury, showing as lowlevel liver enzymes in LLV patients.

The usage of AFP in diagnosing HCC is controversial. A cutoff value of $20 \mathrm{ng} / \mathrm{mL}$ shows high sensitivity but low specificity, whereas a high cutoff value at $200 \mathrm{ng} / \mathrm{mL}$ lowers sensitivity dramatically [18], leading to a non-negligible risk of misdiagnosis. Dynamic changes of AFP levels could also be observed in $\mathrm{CHB}$ patients, showing as elevated AFP levels before antiviral therapy and decreased AFP levels after antiviral therapy in patients with active CHB [19]. In this study, we used a lower cutoff value of $10 \mathrm{ng} / \mathrm{mL}$ and found the proportions of pre- and post-operative AFP levels $<10 \mathrm{ng} / \mathrm{mL}$ were high in both groups. More importantly, in patients with tumor recurrence, there were $35.7 \%(15 / 42)$ patients in group 1 and $27.1 \%(16 / 59)$ patients in group 2 showed AFP levels $<10 \mathrm{ng} / \mathrm{mL}$, respectively. These results suggest that low AFP levels are not safe enough on excluding HCC and tumor recurrence, especially in LLV patients. The effectiveness of AFP at $10 \mathrm{ng} / \mathrm{mL}$ on screening HCC should be more rigorous evaluated in the future. 
There were some limitations in this study. First, metabolism-related fatty liver disease is gradually becoming an important risk factor for HCC. Data on body weight and height were missing in some patients, therefore body mass index could not be calculated and compared between groups. Second, the follow-up time was not long enough in some patients. All these factors should be further studied.

\section{Conclusions}

LLV patients with HCC were characterized by smaller tumor size, less serious liver injury, and lower AFP levels compared to patients with HBV DNA $\geq 2000 \mathrm{IU} / \mathrm{mL}$. Preoperative LLV was related with a long tumor recurrence interval, and complete VR after curative hepatectomy was associated with a lower risk of hepatocellular carcinoma recurrence. A more suitable management strategy should be established to reduce the incidence of HCC in LLV patients. HBsAg levels could be an important indicator for monitoring the effects of antiviral therapy in patients with LLV or even undetectable HBV DNA.

\section{Abbreviations}

ALT: Alanine aminotransferase; ALP: Alkaline phosphatase; AFP: Alphafetoprotein; AST: Aspartate aminotransferase; CHB: Chronic hepatitis B; Cl: Confidence interval; GGT: Y-glutamyl transpeptidase; HR: Hazard ratio; HBeAg: Hepatitis B e antigen; HBsAg: Hepatitis B surface antigen; HBV: Hepatitis B viral; HCC: Hepatocellular carcinoma; LLV: Low-level viremia; VR: Virologic response

\section{Acknowledgements}

Not applicable.

\section{Authors' contributions}

SFR collected data and drafted the manuscript. LZF collected and analyzed data, WBY designed the work and revised the manuscript. All authors have read and approved the manuscript.

\section{Funding}

Not applicable.

\section{Availability of data and materials}

The datasets used and/or analysed during the current study are available from the corresponding author on reasonable request.

\section{Declarations}

\section{Ethics approval and consent to participate}

This study was approved and the need for informed consent was waived by the institutional review board of the First Hospital of China Medical University.

\section{Consent for publication}

Not applicable.

\section{Competing interests}

The authors declare that they have no competing interests.

\section{Author details}

'Department of Elderly Gastroenterology, The First Hospital of China Medical University, Shenyang 110001, China. ${ }^{2}$ School of Pharmacy, China Medical University, Shenyang 110001, China.
Received: 18 January 2021 Accepted: 11 June 2021

Published online: 14 October 2021

\section{References}

1. Caines A, Selim R, Salgia R. The changing global epidemiology of hepatocellular carcinoma. Clin Liver Dis. 2020;24(4):535-47. https://doi.org/1 0.1016/j.cld.2020.06.001 PMID: 33012444

2. Chinese Society of Infectious Diseases, Chinese Medical Association; Chinese Society of Hepatology, Chinese Medical Association. The guidelines of prevention and treatment for chronic hepatitis B (2019 version). Zhonghua Gan Zang Bing Za Zhi. 2019;27(12):938-61. https://doi.org/10.3760/cma.j. issn.1007-3418.2019.12.007 PMID: 31941257.

3. Stanaway JD, Flaxman AD, Naghavi M, Fitzmaurice C, Vos T, Abubakar I, et al. The global burden of viral hepatitis from 1990 to 2013: findings from the global burden of disease study 2013. Lancet. 2016;388(10049):1081-8. https://doi.org/10.1016/S0140-6736(16)30579-7 PMID: 27394647

4. Chen CJ, Yang HI, Su J, Jen CL, You SL, Lu SN, et al. Risk of hepatocellular carcinoma across a biological gradient of serum hepatitis B virus DNA level. JAMA. 2006;295(1):65-73. https://doi.org/10.1001/jama.295.1.65 PMID: 16391218.

5. Jang JW, Choi JY, Kim YS, Yoo JJ, Woo HY, Choi SK, et al. Effects of virologic response to treatment on short- and long-term outcomes of patients with chronic hepatitis b virus infection and decompensated cirrhosis. Clin Gastroenterol Hepatol. 2018;16(12):1954-63 e3. https://doi.org/10.1016/j. cgh.2018.04.063 PMID: 29753085.

6. Kim JH, Sinn DH, Kang W, Gwak GY, Paik YH, Choi MS, et al. Low-level viremia and the increased risk of hepatocellular carcinoma in patients receiving entecavir treatment. Hepatology. 2017;66(2):335-43. https://doi. org/10.1002/hep.28916 PMID: 28012257

7. Kim TS, Sinn DH, Kang W, Gwak GY, Paik YH, Choi MS, et al. Hepatitis B virus DNA levels and overall survival in hepatitis B-related hepatocellular carcinoma patients with low-level viremia. J Gastroenterol Hepatol. 2019; 34(11):2028-35. https://doi.org/10.1111/jgh.14750 PMID: 31157456.

8. Huang G, Li PP, Lau WY, Pan ZY, Zhao LH, Wang ZG, et al. Antiviral therapy reduces hepatocellular carcinoma recurrence in patients with low HBV-DNA levels: a randomized controlled trial. Ann Surg. 2018;268(6):943-54. https:// doi.org/10.1097/SLA.0000000000002727 PMID: 29521740.

9. Terrault NA, Lok ASF, McMahon BJ, Chang KM, Hwang JP, Jonas MM, et al. Update on prevention, diagnosis, and treatment of chronic hepatitis $\mathrm{B}$ : AASLD 2018 hepatitis B guidance. Hepatology. 2018;67(4):1560-99. https:// doi.org/10.1002/hep.29800 PMID: 29405329

10. European Association for the Study of the Liver, European Association for the Study of the Liver. EASL clinical practice guidelines: management of alcohol-related liver disease. J Hepatol. 2018;69(1):154-81. https://doi.org/1 0.1016/j.jhep.2018.03.018 PMID: 29628280.

11. Sun Y, Wu X, Zhou J, Meng T, Wang B, Chen S, et al. Persistent low level of hepatitis $B$ virus promotes fibrosis progression during therapy. Clin Gastroenterol Hepatol. 2020;18(11):2582-91.e6. https://doi.org/10.1016/j. cgh.2020.03.001 PMID: 32147592.

12. Nguyen T, Thompson AJ, Bowden S, Croagh C, Bell S, Desmond PV, et al. Hepatitis B surface antigen levels during the natural history of chronic hepatitis B: a perspective on Asia. J Hepatol. 2010;52(4):508-13. https://doi. org/10.1016/j.jhep.2010.01.007 PMID: 20206400.

13. Seto WK, Liu K, Wong DK, Fung J, Huang FY, Hung IF, et al. Patterns of hepatitis B surface antigen decline and HBV DNA suppression in Asian treatment-experienced chronic hepatitis B patients after three years of tenofovir treatment. J Hepatol. 2013;59(4):709-16. https://doi.org/10.1016/j. jhep.2013.06.007 PMID: 23792029.

14. Tseng TC, Liu CJ, Yang HC, Su TH, Wang CC, Chen CL, et al. High levels of hepatitis B surface antigen increase risk of hepatocellular carcinoma in patients with low HBV load. Gastroenterology. 2012;142(5):1140-9.e3. https://doi.org/10.1053/j.gastro.2012.02.007 quiz e13-4. PMID: 22333950.

15. Cornberg M, Wong WW, Locarnini S, Brunetto M, Janssen HLA, Chan HL. The role of quantitative hepatitis B surface antigen revisited. J Hepatol. 2017; 66(2):398-411. https://doi.org/10.1016/j.jhep.2016.08.009 PMID: 27575311.

16. Mak LY, Seto WK, Fung J, Yuen MF. Use of HBsAg quantification in the natural history and treatment of chronic hepatitis B. Hepatol Int. 2020;14(1): 35-46. https://doi.org/10.1007/s12072-019-09998-5 PMID: 31745711.

17. Goh BK, Teo JY, Chan CY, Lee SY, Jeyaraj P, Cheow PC, et al. Importance of tumor size as a prognostic factor after partial liver resection for solitary hepatocellular carcinoma: implications on the current AJCC staging system. 
J Surg Oncol. 2016;113(1):89-93. https://doi.org/10.1002/jso.24099 PMID: 26611492.

18. Trevisani F, D'Intino PE, Morselli-Labate AM, Mazzella G, Accogli E, Caraceni $P$, et al. Serum alpha-fetoprotein for diagnosis of hepatocellular carcinoma in patients with chronic liver disease: influence of $\mathrm{HBsAg}$ and anti-HCV status. J Hepatol. 2001;34(4):570-5. https://doi.org/10.1016/s0168-82 78(00)00053-2 PMID: 11394657

19. Shim JJ, Kim JW, Lee CK, Jang JY, Kim BH. Oral antiviral therapy improves the diagnostic accuracy of alpha-fetoprotein levels in patients with chronic hepatitis B. J Gastroenterol Hepatol. 2014;29(9):1699-705. https://doi.org/1 0.1111/jgh.12612 PMID: 24730702

\section{Publisher's Note}

Springer Nature remains neutral with regard to jurisdictional claims in published maps and institutional affiliations.

Ready to submit your research? Choose BMC and benefit from:

- fast, convenient online submission

- thorough peer review by experienced researchers in your field

- rapid publication on acceptance

- support for research data, including large and complex data types

- gold Open Access which fosters wider collaboration and increased citations

- maximum visibility for your research: over $100 \mathrm{M}$ website views per year

At BMC, research is always in progress.

Learn more biomedcentral.com/submissions 